\title{
SURVEY OF ROOT KNOT DISEASE OF SPONGE GOURD (Luffa cylindrica) AT MUZAFFARPUR IN CITY AREAS
}

\author{
GAZALA RUHI FATMA ${ }^{\mathrm{a} 1}$ AND S.N. SINGH ${ }^{\mathrm{b}}$ \\ ${ }^{a b}$ Department of Zoology, B.R. Ambedkar Bihar University, Muzaffarpur, Bihar, India
}

\begin{abstract}
Root knot disease is caused by plant parasitic nematodes. In the present study, four areas of Muzaffarpur town were selected where sponge gourd is being cultivated at small scale. These areas were visited from July to October. It was noted that plants were healthy and fruits were normal up to August. However, in September, Chlorotic patches were seen on the leaves of above vegetable crops. This became more prominent in October. It was further noted that the leaf size was reduced, the newer leaves were bunched, flowering was reduced and fruits were deformed. Fruit set was completely abnormal. Deformed fruits were present and growth of the new branches was retarded. The roots of these plants had galls however; they were 8-10 in number per plant. In Octobers the number of galls, and size increased. Entire roots were deformed due to gall formation. Certain gall just near the surface of soil was corky and larger in shape. Such roots were carefully collected and their number per plants, size etc. were studied in different localities. All such roots as well as soil taken from the rhizosphere was used for the isolation of the parasite. Slides were prepared and based on the microscopic study and number the nematode was identified. Gall formation varied in different localities of the town. Where repeated cultivation of these vegetables were done and the land had continuous source of water from the surrounding buildings revealed maximum galls per plants. However, where plantation was not regular and field was dry, the number and size of galls were much lower. It was observed that the frequency of galls were much lower in the area where there was no source of sewage. Eco-friendly, non synthetic chemical, means of control measure have been suggested. Here field sanitation, plaughing during summer, crop rotation with non host, organic amendment co-cultivation of plants having antagonistic effect on nematodes, trap crops etc. were advised. Some of the farmers followed these and in next year there was reduction in the disease incident.
\end{abstract}

KEYWORDS: Root Knot, Sponge Gourd, Galls, Chlorotic Patches, Deformed Fruits, Eco-Friendly

Sponge gourd (Luffa cylindrica) of the family Cucurbitaceae are most popular and easily available vegetable in North Bihar. Because of its market value, easy to cultivate these crops are being cultivated at both small and large scale. All those living in the urban areas, if they have a small piece of land in their campus they do cultivate these vegetables. Because, they are climber so they need small areas for their cultivation. However, in certain localities these vegetables crops are severely damaged by the plant parasitic nematode that causes damage to the root systems due to which the absorption of water and nutrients and their translocations are disturbed. Their impacts are visible on the above ground parts as well the below grounds parts. These symptoms are more apparent in late September to October and in case of severe infection complete plants are affected and there is no fruiting at all. Farmers now uproot such plants and dump them in the corners of the field. Although it is reported that the loss may $17-25 \%$ on an average basis, in the present study $100 \%$ loss was noted in certain areas of the town.

Root knot disease causing nematodes are polyphagous, and obligate plant parasites. The primary inoculums of the pathogen are from the soil where they survive on the debris of the host plants or on the alternative hosts particularly the weeds. Even in the nurseries the pathogen may be present along with the seedlings. Contaminated soil, the irrigation water coming through such soil may be the source of primary inoculums. The spread of root knot disease is generally due to unawareness as even today, farmers do not know about it. Now phytonematodes are considered as one of the major pests of high valued agricultural crops. The degree of damage done depends upon the pathogenic potential and population growth of nematodes which are greatly influenced by their initial population densities and climatic conditions (Chandra et al., 2010).

Similarly, soil texture crop cycle, and anthropogenic factors also influence the disease incidence. (Chirchir et al., 2010). Jain et al., (2007) reported that annual loss of Rs. 547.5 Million in cucurbits is caused by root knot nematode (Meloidogyne sp.) that is most important group of plant parasitic nematodes. Root knot nematodes are worldwide in distribution (Sassar, 1980). Their worldwide distribution, extensive host range and interaction with other plant pathogens in disease complexes rank them among the major plant pathogens in the world.

There are large numbers of reports related with root knot disease causing nematodes. Some of them may

${ }^{1}$ Corresponding author 
be cited here such as Barker and Olthof (1976), Ogunfowna (1977), Sessar (1980), Ganguly and Dasgupta (1983), Singh and Khare (1984), Reddy (1985), Darekar et al., (1988), Mohanty et al., (1995), Patel et al., (1996), Mahapatra et al., (1999), Pathak et al., (2000), Khan and Kumar (2003), Khan (2003), Khan et al., (2004), Krishnaveni and Subramanian (2005), Kumar and Pathak (2005), Joymati and Meena (2007), Patel et al., (2007), Roy et al., (2007), Giri Babu et al., (2008), Indu Rani et al., (2008), Sao et al., (2008), Vovlas et al., (2008), Ahmad and Suleman (2009), Nath et al., (2009), Zaki et al., (2009), Chandel et al., (2010), Rathod et al., (2010), Zarina nd Shahina (2010), Chaudhary et al., (2011), Sahu et al., (2011), Sajid et al., (2011), Singh and Kumar (2013), Tamil selvi et al., (2013), Gautam et al., (2014), Ngele and Kulu (2015), Tamil Silvi (2017), Pandey and Nayak (2018). Therefore, present study was planned to survey the root knot disease of sponge gourd by plant parasitic nematode Meloidogyne incognita, was done in the different localities of the main town Muzaffarpur.

\section{MATERIALS AND METHODS}

A field survey of four different localities of Muzaffarpur city was conducted. These localities were MIT, Ramdayalu Nagar, Bela Industrial Areas and in the Ramna. It was found that cultivated area at MIT was not surrounded by houses, and there was no continuous flow of water in it. There was no dumping of domestic waste there. In Bela and Ramna areas the cultivated land was in the campus. Here the campus in Ramna the land was North to the main building so the cultivated areas were under shady conditions most of the year. While the campus in Bela was in the South to the building so it was exposed for maximum time to sunlight.
The area in Ramdayalu was upland and there was always dry condition in the field. These fields were selected on the basis of above ground symptoms of the crop such as wilting, slow growth, reduced and deformed leaves, presence of chlorotic patches on the leaves. Roots and rhizospheric soil were collected by digging from a depth of 10-15 cm. Such samples were collected from the four corners and central part of the field. Both roots and soil collected were taken in a well cleaned polythene bags. It was brought in the laboratory and stored at low temperature. Collection was done in late September and mid October. Roots were cleaned properly and total number of galls per palnt was counted. Even the size, texture, presence of secondary galls etc. were studied. Nematodes were extracted by Cobb's sieving and decanting method followed by Baermann's funnel technique (Southey, 1985) and the nematode suspensions was collected. These nematodes were killed and stained for microscopic study. The width and length were measured with the help of micrometer. Here the microscopic constant was also calculated before the measurement. Number of galls per plant was also calculated among the root samples collected from the four places of Muzaffarpur city. Once the disease was located the growers of such field were discussed and eco-friendly control measures such field sanitation, weeds eradication, destruction of the infected plants, antagonistic plants cultivation, Trap plant species cultivation rotation with non-host crops organic amendment etc. were suggested to them. Some of them followed it and next year, there were considerable reduction in the disease incidence as well the number of galls per plants. Data obtained have been presented in Table 1 to 3 .

Table 1: Showing number of galls, their size, texture etc. in sponge gourd (Luffa cylindrica) cultivated at different location at Muzaffarpur

\begin{tabular}{|c|c|c|c|c|c|}
\hline Locality & $\begin{array}{c}\text { Number of } \\
\text { galls }\end{array}$ & Texture & Size & $\begin{array}{c}\text { Secondary } \\
\text { galls }\end{array}$ & $\begin{array}{l}\text { Health of the } \\
\text { roots }\end{array}$ \\
\hline Ramna Campus & 88.54 & Corky & $\begin{array}{c}\text { Large } 1.6 \text { inch } \\
\text { in diameter }\end{array}$ & Present & $\begin{array}{l}\text { Decaying } \\
\text { condition }\end{array}$ \\
\hline $\begin{array}{c}\text { Ramdayalu } \\
\text { Nagar Campus }\end{array}$ & 56.72 & $\begin{array}{l}\text { Few corky, rest } \\
\text { smooth }\end{array}$ & $\begin{array}{c}\text { Less than one } \\
\text { inch in diameter }\end{array}$ & Absent & Poor branching \\
\hline Bela Campus & 67.85 & Corky & $\begin{array}{l}\text { Some } 1.0 \text { inch } \\
\text { in diameter }\end{array}$ & Absent & $\begin{array}{c}\text { Tips of } \\
\text { secondary roots } \\
\text { necrotic }\end{array}$ \\
\hline MIT campus & 44.38 & Smooth & $\begin{array}{l}\text { Less than } 1.0 \\
\text { inch in diameter }\end{array}$ & Absent & Poor branching \\
\hline
\end{tabular}


FATMA AND SINGH: SURVEY OF ROOT KNOT DISEASE OF SPONGE GOURD (Luffa cylindrica) AT MUZAFFARPUR...

Table 2: Showing the population of the nematode and its juvenile $\mathrm{J} 2$ stage in 200 cc of soil taken from the rhizosphere of the infected plants from different localities

\begin{tabular}{|c|c|c|c|}
\hline Locality & Population of Nematode & Population of J2 & Gall index \\
\hline Ramna Campus & 248.52 & 3724.46 & 5 \\
\hline Ramdayalu Nagar Area & 182.64 & 2268.36 & 4 \\
\hline Bela Campus & 222.72 & 2405.24 & 4 \\
\hline MIT Campus & 162.28 & 1971.32 & 4 \\
\hline
\end{tabular}

Gall Index: $2=1-10$ galls, $3=11-30$ galls, $4=31-75$ galls, $5=76-100$ galls

Table 3: Impact of different control measures on root knot disease incidence of sponge gourd caused by Meloidogyne incognita

\begin{tabular}{|c|c|c|c|c|c|c|c|c|}
\hline \multirow{2}{*}{ Treatments } & \multicolumn{7}{|c|}{ Locality + Number of galls } \\
\cline { 2 - 9 } & A & NG & B & NG & C & NG & D & NG \\
\hline $\begin{array}{c}\text { Neem cake }+ \\
\text { Vermicompost }\end{array}$ & A & 42.18 & B & 21.34 & C & 28.74 & D & 19.52 \\
\hline $\begin{array}{c}\text { Neem cake }+ \\
\begin{array}{c}\text { Vermicompost } \\
+ \text { Marigold }\end{array}\end{array}$ & A & 16.58 & B & 12.42 & C & 14.15 & D & 12.84 \\
\hline $\begin{array}{c}\text { Deep plaughing } \\
+ \text { Neem Cake }+ \\
\begin{array}{c}\text { Vermicompost }+ \\
\text { Marigold }\end{array}\end{array}$ & A & 7.82 & B & 6.58 & C & 7.38 & D & 7.15 \\
\hline
\end{tabular}

\section{RESULTS AND DISCUSSION}

It was observed that samples collected from all the areas exhibited presence of root knot nematodes. However, all four fields present at different areas had variations with respect to the number as well as size of the galls. Nematodes were isolated from the roots as well as form the rhizospheric soil, as described in Materials and Methods. The females, males and juvenile 2 stages were observed and with the help of the standard text the species was confirm. Form the table 1, it may be noted that the highest number of galls in the roots of the infected plant of sponge gourd was 88.54, where the specimen was collected from Ramna campus. This was followed in the roots collected from Bela campus 67.85, Ramdayalu Nagar Campus 56.72 and MIT campus 44.38.

The texture of the galls, in the roots collected form Ramna campus was Corky, the size was larger than 1.6 inch in diameter and even the secondary galls were present in this sample. The roots had decaying portion galls of the roots collected form Bela campus were also Corky but their size was only 1.0 much in diameter and no secondary galls. The tips of secondary roots were necrotic. The galls in the roots collected form Ramdayalu Nagar were few Corky and rest smooth. Their size had less than one inch diameter, there was no secondary galls and roots revealed poor branching. Galls in the roots collected from MIT campus were smaller, smooth, and had no secondary galls. Here the branching was also poor. So it may be concluded that number, size and texture of the galls depend on the soil condition, nutritional status and intensity of the infection. Enlarge corky galls with secondary gall indicates severe infection where as smooth, small and without secondary gall the infection may be mild.

From the table it may be noted that population of nematodes and juvenile-J2 and the gall index varied considerably in the samples collected from different localities. Here in $200 \mathrm{cc}$ of soil sample the highest number of nematodes 248.52 and the J2 3724.24 and the gall index 5 were observed in the sample collected from Ramna campus, followed by Bela campus, 222.72, 2405.24 and 4, followed by Ramdayalu Nagar, 182.64, 2268.36, 4 and finally 162.28, 1971.32 and 4 in the sample collected form MIT campus. Here again the sample collected from MIT revealed the lowest data for all the parameters considered. This may be correlated with the soil type, the moisture and the nutrient components of the field. In Ramna, these components were suitable and hence for better growth, while at MIT it was not suitable so poor growth of the different stages of Nematodes, Meloidogyne incognita. Present findings 
FATMA AND SINGH: SURVEY OF ROOT KNOT DISEASE OF SPONGE GOURD (Luffa cylindrica) AT MUZAFFARPUR...

corroborate with the findings of Chandra et al., (2010), Tamil Selvi et al., (2013), Tamil selvi et al., (2017) respectively.

Local growers were discussed about the disease and they expressed their ignorance about it. Then everything was explained to them. They were advised to follow the strategies of the control o the disease in different area of their field. Next year same locality and same field was visited. The growers were asked about the methodology to be following for its control. All the growers adapted different methods which were recorded. The samples of infected fruits were collected and analysed. The data were placed in table-3.

From the table it was clear that there was reduction in the number of galls in the infected plants according to the control measure used. It was found that maximum reduction in the number of galls was found in the field when deep plaughing during summer, was done. Further the land was supplemented with neem cake, vermicompost and there was co-cultivation of marigold. The number of galls was 7.82 per plant at Ramna campus, 6.58 at Ramdayalu Nagar, 7.38 in Bela campus and 7.15 in MIT campus. After the study they were advised to follow the control measures such as deep plaughing, neem cake ( $1 \mathrm{~kg} /$ plant) vermicompost $(1 \mathrm{~kg} /$ plant $)$ and cocultivation of marigold. They also revealed that debris of plants were destroyed by burning, weeds were also eradicated.

\section{CONCLUSION}

Root knot disease of sponge gourd caused Meloidogyne incognita is an important disease about whom the growers know nothing. It is essential that there should be mass awareness about it and its control measures.

\section{ACKNOWLEDGEMENT}

The authors are thankful to the professor and Head, Department of Zoology, B.R. Ambedkar Bihar University, for providing Library and Laboratory facilities to carry out the work.

\section{REFERENCES}

Ahmad A.I. and Suleman N.A., 2009. Susceptibility of some cucurbitaceous plants to root knot nematode Meloidogyne incognita Plant Protection, 28: 108-110.
Barke K.R. and Olthof T.H.A., 1976. Relationships between nematode population densities and crop response. Ann. Rev. Phytopathol., 14: 327-353.

Chandel Y.S., Kumar S., Jain R.K. and Vashisth S., 2010. An analysis of nematode problems in green house cultivation in Himachal Pradesh and avoidable losses due to Meloidogyne incognita in tomato. Indian Jour. Nematol., 40(2): 198203.

Chandra P., Sao R.S., Gautam K. and Poddar A.N., 2010. Initial population density and its effect on the pathogenic potential and population growth of root knot nematode (Meloidogyne incognita) in four species of cucurbits. Asian J. Plant Pathol., 4(1): $1-15$

Chaudhary K.K., Daniel B., Okube H., Zaid T., and Dagnew E., 2011. Distribution frequency of occurrence and population density of root knot nematode in Amelmano. African J. of Microbiology Research, 5(31): 5656-5661.

Chirechir A.K., Kimanju J.W., Olubayo F.M. and Mutua G.K., 2008. Abundance and distribution of plant parasitic nematode, associated with sugarcane in Kenya. Asian J. Plant Pathol., 2: 48-53.

Cob N.A., 1918. Estimating the nematode population of soil. USDA, Technology Circular, 1: 1-48.

Darekar K.S., Mhase N.L. and Shelke S.S., 1988. Relative susceptibility of cucumber varieties/lines, to the root knot nematode Meloidogyne incognita race-3, Int. Nemato. Network Newsl., 5(1): 16-17.

Ganguly A.K. and Dasgupta D.R., 1983. Chemical changes in brinjal plants induced by root knot nematode Meloidogyne incognita Indian J. of Entomology, 45: 45-47.

Gautam S.K., Sahu G., Verma B.K. and Poddar A.N., 2014. Status of root knot nematode (Meloidogyne sp.) disease in vegetable crops of some districts of Chhattisgarh. African Journal of Microbiol. Res., 8(16): 1663-1671.

Giri Babu P., Singh R.V. and Munshi A.D., 2008. Pathogenicity of root knot nematode (Meloidogyne incognita Race-I) on ridge gourd (Luffa acutangula) and sponge gourd (Luffa cylindrica) Ind. J. Nematol., 38: 255-257. 
FATMA AND SINGH: SURVEY OF ROOT KNOT DISEASE OF SPONGE GOURD (Luffa cylindrica) AT MUZAFFARPUR...

Indurani C., Veeraragavathatham D. and Sangeetha S., 2008. Analysis on biochemical basis of root knot nematode Meloidogyne incognita resistance in tomato (Lycopersicon esculentum). Res. J. Agric. Bio. Sci., 4(6): 866-870.

Jain R.K., Mathur K.N. and Singh R.U., 2007. Estimation of losses due to plant parasitic nematodes on different crops in India. Indian J. Nematol., 37(2): 219-221.

Joymati L. and Meena M., 2007. Association of Meloidogyne incognita and other plant parasitic nematodes with different crops of Manipur. Zoo Print Journal, 22(12): 2933-2934.

Khan M.R., 2003. Life cycle, pathogenecity and management of root knot nematode, Meloidogyne incognita race-II infecting Balsam (Impatiens balsanina L.) Indian J. Nematol., 33: $72-73$.

Khan T.A., NIsar S. and Ashraf M.S., 2004. Effect of population levels of Meloidogyne javanica on plant growth and nematode multiplication on cucurbits. Pak. J. Nematol., 22: 83-89.

Khan A.S. and Kumar S., 2003. Assessment of avoidable yield losses in Momordica charantia due to Meloidogyne incognita race-II. Indian J. Hill Farming, 16(1\&2): 111-112.

Krishnaveni M. and Subramanian S., 2005. Root knot nematodes of Cucurbits and their managementA review. Agric. Rev., 26(2): 103-113.

Kumar M. and Pathak R.N., 2005. Influence of Meloidogyne incognita on germination, seedling emergence and plant growth of lettuce (Lectuca sativa L.). Ann. Plant Protect Sci., 13: 224-229.

Mahapatra S.N., Swain P.K. and Behera B., 1999. Pathogenecity and management of root knot nematode (Meloidogyne incognita) in pointed gourd (Trichosanthes dioica). Indian J. Agric. Sci., 69(4): 275-277.

Mohanty K.C., Swain S.C. and Pradhan T., 1995. Biochemical variations in resistant and susceptible brinjal varieties, infected by root knot nematode $M$. incognita. Ind. J. of Nematology, 25: 142-146.

Nath R.C., Sinha B.C., Mukherjee B. and Dasgupta M.K., 2009. Community analysis and diversity of plant parasitic nematodes associated Litchi plantation in North Tripura District. Pest Manage. Horticult. Ecosyst. 15: 51-59.

Ngele K.K. and Kalu U.N., 2015. Studies on different species of plant parasitic nematodes attacking vegetable crops- in Nigeria. J. Agric. Food Sci., 3(4): 88-92.

Ogunfowora A.O., 1977. Effect of different population levels of Meloidogyne incognita on the yield of Tomato Lycopersicon esculentum in the South Western Nigeria. Plant Prot., 3: 61-67.

Pandey R.K. and Nayak D.K., 2018. Assessment of avoidable yield loss due to root knot nematode Meloidogyne incognita infesting Luffa acutangula L. J. of Entomology and Zoology Res., 6(5): 911-914.

Patel A.D., Panikar B.K., Patel B.A. and Patel D.J., 2007. Community analysis of plant parasitic nematodes associated with agricultural crops in Junagadh district of Gujarat and Diu, Union Territory. Ind. J. Nematol., 37: 68-71.

Patel M.B., Patel D.J. and Patel B.A., 1996. Pathogenic effects of Meloidogyne incognita and $M$. javanica on cotton. Afri. Asian J. Nematol., 6: 156-161.

Pathak K.N., Keshari N. and Hyder M.G., 2000. Effect of population levels of Meloidogyne incognita on seed germination and seedling emergence and plant growth of Cauliflower. Indian J. Nematol., 30: $12-18$.

Rathour K.S., Dubey J. and Ganguly S., 2010. Documentation of plant parasitic and beneficial nematodes and their communities in Madhya Pradesh, India. Ind. Jour. Nematol., 40(1): 6673.

Reddy D.D.R., 1985. Analysis crop losses in tomato due to Meloidogyne incognita. Indian J. Nematol., 15: 55-59.

Roy K., Mukhopadhyay A.K. and Pranadhik A., 2007. Community analysis of plant parasitic nematodes associated with leguminous vegetables crops in West Bengal. Ind. J. Nematol., 37: 58-62.

Sahu R., Chandra P. and Poddar A.N., 2011. Community analysis of plant parasitic nematodes prevalent in vegetable crops in District Durg of 
FATMA AND SINGH: SURVEY OF ROOT KNOT DISEASE OF SPONGE GOURD (Luffa cylindrica) AT MUZAFFARPUR...

Chhattishgarh, India. Research Journal of Parasitology, 6(2): 83-89.

Sajid A.K., Najir K., Kamran M., Haque I.V. and Haque M.A., 2011. Invasion and development of Meloidogyne incognita race-1 in different tomato cultivars. Pak. J. Nematol., 29(1): 63-70.

Sao R., Chandra P. and Poddar A.N., 2008. Prevalence of root knot nematode (Meloidogyne incognita) infection in vegetable crops in Chhattishgarh. Bionature, 28(2): 61-67.

Sasser J.N., 1980. Root knot nematodes: a global menace to crop production. Plant Dis., 64: 36-41.

Singh R.K., Jola D. and Sudershan G., 2010. Documentation of plant parasitic and beneficial nematodes and their communities in Madhya Pradesh. Ind. J. Nematol., 40: 66-73.

Singh R.V. and Khera S., 1984. Plant parasitic nematode associated with vegetable crops around Calcutta. Indian J. Nematol. 14(1): 188-189.

Singh R. and Kumar U., 2013. Assessment of nematode distribution and yield losses in vegetable crops of Western U.P., India. Int. J. Sci. and Res., 4(5): 2812-2816.
Southey J.F., 1985. (Ed) Laboratory methods for work with plant and soil nematodes.

Tamil selvi N.A., Pugalendhi L.P. and Sivakumar M., 2017. Response of cucurbitaceous root stocks, and bitter gourd scions to root knot nematode Meloidogyne incognita kofoid. Int. J. of Horticulture and Floriculture, 5(1): 247-251.

Vovlas N., Lucarelli G., Sasavelli N., Troccoli A., Papajova I.C., Palomares Rivs J.E. and Castillo P., 2008. Pathogenecity and host parasite relationships of root knot nematode, Meloidogyne incognita on Celery. Plant Pathol., 57: 981-987.

Zaki A., Siddiqui M. and Aktar S., 2009. Effects of antagonistic fungi, plant growth promoting rhizobacteria and arbuscular mycorrhizal fungi alone and in combination on reproduction of Meloidogyne incognita and growth of tomato. J. Gen. Plant Pathol., 75: 144-153.

Zarina B. and Shahina F., 2010. Research work carried out on the management of root knot nematode disease in Pakistan. Pak. J. Nematol., 28(2): 153-239. 